\title{
Development of Augmented Reality-Based Interactive Multimedia to Improve Critical Thinking Skills in Science Learning
}

\author{
Ahmad Syawaludin \\ S.Pd., Master Student, Postgraduate Program, Universitas Sebelas Maret, Indonesia, \\ syawaludinahm@student.uns.ac.id

\section{Gunarhadi} \\ Prof., Teacher Training and Education Faculty, Universitas Sebelas Maret, Indonesia, \\ gunarhadi@fkip.uns.ac.id

\section{Peduk Rintayati} \\ Dr., Teacher Training and Education Faculty, Universitas Sebelas Maret, Indonesia, \\ pedukrintayati@staff.uns.ac.id
}

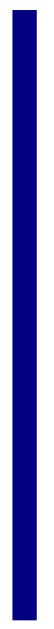

This study aimed to describe the development of augmented reality-based interactive multimedia to improve the critical thinking skills of elementary school teacher education students in learning earth structure and fisheries material science. This type of research was research and development by Sukmadinata consisting of preliminary studies, model development, and model testing. The research subjects were elementary school teacher education students at Sebelas Maret University, Indonesia. The technique of collecting data used tests, questionnaires, and observations. The collected data was then analyzed qualitatively and quantitatively. Qualitative data analysis used the interactive models of Miles and Huberman and quantitative data analysis using a paired sample t-test. The results of the study show that the development of media products determines indicators of learning, programming, display, and curriculum. The main field test obtained pvalue $=$ $0.002<0.05$, it can be decided that H0 rejected. Students think critically using augmented reality-based interactive multimedia better than before using it. At present, it is obtained interactive multimedia based on augmented reality that is feasible to use in accordance with the views of experts and users.

Keywords: augmented reality, critical thinking skills, elementary school teacher education, multimedia interactive, science learning

Citation: Syawaludin, A., Gunarhadi, \& Rintayati, P. (2019). Development of Augmented RealityBased Interactive Multimedia to Improve Critical Thinking Skills in Science Learning. International Journal of Instruction, 12(4), 331-344. https://doi.org/10.29333/iji.2019.12421a 


\section{INTRODUCTION}

As a professional teacher candidate, elementary school teacher education students need to master learning material widely and deeply which includes mastering the substance of the content of learning materials, and can solve problems as a manifestation of critical thinking skills in science learning. Critical thinking skills are needed by prospective science teachers (including in elementary schools) who are responsible for their professional development in leading students to become scientifically literate. The goals of critical thinking for giving evidence of the cases, interpreting what happened, and solving the problem (Irawan, Rahardjo, \& Sarwanto, 2017). Critical thinking basically involves a process of logic, reasoning, and decision making (Afandi \& Sajidan, 2017). Critical thinking skills are needed by students to carry out a series of scientific methods to answer problems in science learning.

The measurement results of critical thinking skills in elementary school teacher education students obtained an average score of 63.99 . The reasoning ability, the collection of relevant and credible information, and the ability of successive interpretations scored 74.34; 71,71; and 69.74. The argumentation ability, ability to assess inference, and ability to make decisions include three aspects of critical thinking skills with the lowest score obtained in elementary school teacher education students with a score of $61.18 ; 55.26$; and 51.32. These results indicate that critical thinking skills in elementary school teacher education students are not satisfactory and need to be improved.

The results of preliminary study show that the available learning media of earth and rock structures are still incomplete. Earth structure media are not available in elementary school teacher education programs. Media limitations have not supported interactive learning and have not been oriented towards empowering critical thinking skills. This can be seen from the results of observations which indicate that there are no indicators of critical thinking in the learning process, such as student activities in reasoning, gathering information, interpreting data, analyzing data, arguing, and solving problems. This situation is urgent for the development of interactive learning media to support effective science learning in primary school teacher education programs.

Technology is growing rapidly and is widely used to develop learning media, such as interactive multimedia. Interactive multimedia presents material effectively, efficiently, and more interestingly to help students achieve learning outcomes. Interactive multimedia can be used to improve good understanding in order to improve the ability of students to solve problems in science, especially about the structure of the earth and rocks. Interactive multimedia development can be done using a smartphone. The availability, sophistication, and use of these devices have the potential to increase efficiency and effectiveness in teaching and learning, learning outcomes, and skills (Morris \& Lambe, 2017).

The results of field studies show that all elementary school teacher education students who contract science subjects have smartphones. Although all students already have smartphones, the use of smartphones as learning media in science materials is still not 
optimal. This indicates that the integration of technology and media as a form of $21^{\text {st }}$ century learning in elementary school teacher education programs is still quite lagging behind. In order to improve the critical thinking skills of elementary school teacher education students in science learning, the development of interactive multimedia based on augmented reality (AR) can be accessed using a smartphone owned by students. This has become something new because the development of AR-based interactive multimedia in science learning, especially earth and rock structures in primary school teacher education has never been done

Augmented reality (AR) allows virtual objects produced by computers to be placed on physical objects in real time (Ozdemir, et al., 2018). Combining the real world and the virtual world makes the boundary between the two very thin. AR as systems that have the following three characteristics: (1) Real and virtual combines; (2) Interactive in real time; (3) Registered in 3-D (Azuma, 1997). AR technology can load a video, sound, photos, text, 3D models (Tekedere \& Göker, 2016; Liang \& Roast, 2014). Users can interact with virtual objects that are inserted in real scenes around them and obtain real human-computer interaction experiences (Cai, et al., 2014). The use of AR technology in learning allows students to explore the world in an interactive and collaborative way (Antonioli, et al., 2014; Martín-Gutiérrez et al., 2010). Its use is in accordance with the idea of constructivism learning because learners can control their own learning process and manipulate unreal objects in an enlarged environment to gain understanding (Wang, 2012). AR-based interactive multimedia provides facilities for 3D interaction with users which will make certain concepts easy to learn for students (Martín-Gutiérrez et al., 2010). Information delivered by virtual objects helps users perform tasks in the real world (Kesim \& Ozarslan, 2012).

AR offers us new ways to interact with the physical world and change the way people learn with mobile devices ( Joan, 2015;Grubert \& Grasset, 2013;Haag, 2013). Uniquely, the application of AR technology in learning earth and rock structures at elementary school teacher education program will give students the opportunity to deepen their knowledge in different ways. Through the use of AR-based interactive multimedia, students seem to see objects actually, for example, an earth slice that looks layers in it, various types of rocks that can be seen a form, color, and special characteristics of rock types. This technology can be utilized so that learning media becomes more interesting, more concise, without reducing the essence of the material. Estapa \& Nadolny (2015) evaluated the achievements and motivations of students in mathematics learning using augmented reality media. Printed books combined with AR were then applied in mathematics learning. The results showed that the use of AR technology in mathematics lessons improved student achievement and student motivation. This research applies AR technology to science learning and emphasizes more on the use of interactive multimedia.

The existence of learning media is indicated could to improve the learning process. Therefore, various educational studies in Indonesia seek to develop learning media and study their effects on the learning process. Some of these studies include the development of takbulta (Susetyarini, A, Fitriasari, \& Fauzi, 2018), i-inverbrata 
(Widiansyah, Indriwati, Munzil, \& Fauzi, 2018), and several other innovative learning media (Arista \& Kuswanto, 2018; Puspitarini, Akhyar, \& Djono, 2018; Rajendra \& Sudana, 2018). From the various studies, it can be seen that the development of ARbased media is still rare in Indonesia, especially in primary school teacher education. Therefore, the purpose of this study is to develop AR-based interactive multimedia in earth and rock structures in primary school teacher education.

\section{METHOD}

\section{Research Design}

This study was a type of Research \& Development (R \& D) Model by Sukmadinata (2013) which consisted of preliminary studies, model development, and model testing. The products in this study are interactive multimedia based on augmented reality in learning earth and rock structure material science in elementary school teacher education programs. The steps of research and development in this study followed the development phase of the model consisting of design validation, preliminary field testing, and playing field testing. The multimedia prototype was then validated by experts to get input and suggestions until they got the approval of the expert team. The experts involved were two, consisting of experts on earth and rock structure materials, and experts in learning media. Meanwhile, main field testing in this study used preexperimental research methods with pretest-posttest one group design.

\section{Participant}

The subjects of this study were elementary school teacher education study students at Sebelas Maret University, Indonesia. The preliminary field testing phase involves 10 students, and the playing field testing involves 34 students. The selection of research subjects using purposive sampling, which is to determine the sample with specific objectives and considerations. The selected students are third-semester students who contract science education courses.

\section{Data Collection Techniques and Instruments}

Data collection research used tests, questionnaires, and observations. Descriptive tests aim to measure the critical thinking skills of elementary school teacher education students on earth structure and rock material. The validity of the test used Aiken's V validity with an error rate of $5 \%$ is 0.78 . The results of the validity of the test instruments indicate that there were ten valid questions, and there were two invalid questions. The reliability of the test used alpha Cronbach obtained avalue of 0.784 . Refer to the value of $\mathrm{r}$ at the confidence level of $95 \%$ or significance of $5 \%(\mathrm{p}=0.05)$ with $0.784>0.4428$, so that the test instrument is reliable.

The questionnaire instrument aims to determine students' responses to AR-based interactive multimedia prototypes in learning earth and rock structures. The questionnaire instrument includes aspects of learning, programming, and display. The validity of the questionnaire used product moment correlation. At the significance of $5 \%$, df $=8$, then obtained $r_{\text {table }}$ of 0.632 . All items have a calculated $r_{\text {value }}>r_{\text {table }}$ so that all questionnaire items are valid. The questionnaire reliability used alpha Cronbach with 
the acquisition of an alpha value of 0.971 . The value of $\mathrm{r}$ at the confidence level of $95 \%$ or significance of $5 \%(\rho=0.05)$ with a value of $\mathrm{df}=10-2=8$ is 0.4428 . Thus, it can be seen that the questionnaire instrument used is reliable.

\section{Data Analysis}

The data analysis technique of this study used interactive data analysis models from Miles and Huberman. This model has three components, consisting of data reduction, display data, conclusion drawing (verification). The data analysis phase starts after the data is collected. All research data collected were selected and selected (data reduction) on what should be presented and used (data display) (Miles \& Huberman, 1994). The data presented becomes clearer to be used as a basis for drawing conclusions. In the main field testing, the data was analyzed used paired sample t-test with a significance level of $5 \%$. Analysis prerequisite test was the variable to be analyzed has a normal distribution. The normality test in this study used the Kolmogorov-Smirnov. Tests were conducted with the aim to determine whether there were differences in the scores of critical thinking skills in elementary school teacher education students before and after learning using AR-based interactive multimedia.

\section{FINDINGS}

\section{Prototype Development and Design Validation}

The preparation of an interactive multimedia prototype based on augmented reality (AR) began with analyzing the curriculum which is intended to determine the material to be published in the media. It is intended that the media developed can help students effectively master the material that can teach it correctly. The scope of earth and rock structure material at elementary school teacher education program is presented in Table 1.

Table 1

The Scope of Earth Structure and Rocks Material in Primary School Teacher Education

\begin{tabular}{ll}
\hline Competence & Indicators \\
\hline & Analyzing the shape of the earth \\
& Model the structure of the earth \\
& Analyzing the theory of continental drift \\
& Identify evidence of the truth of the theory of continental drift \\
Assessing Earth and & Analyze endogenous impacts \\
Rock Structures & Analyze earthquake cases \\
& Describe rock cycle models \\
& Identify igneous rocks \\
& Identify sedimentary rocks \\
Identify metamorphic rocks
\end{tabular}

The products produced were AR-based interactive multimedia in the form of applications that can work on an Android system. The use of this media is integrated with teaching materials that contain markers to support the performance of AR technology. Interactive multimedia based on augmented reality in learning earth and 
rock structures has a logo that reads "ESR" which stands for earth structure and rock presented in Figure 1.

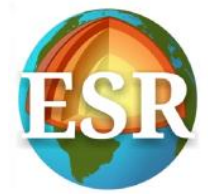

Figure 1

ESR Logo

Multimedia developed has 3 main menus consisting of AR camera, quiz, and about. Camera AR serves to display the desired 3D image. The camera is sufficiently directed to two-dimensional images that are in teaching materials, and will automatically display interesting and more realistic 3D images. Figure 2 is an example of the appearance of 3D sedimentary rock objects that work through augmented reality technology. In addition to $3 \mathrm{D}$ objects, this multimedia can provide animations and videos to make it easier for students to understand the concepts of earth and rock structures, for example the addition of earth convection animation presented in Figure 3.
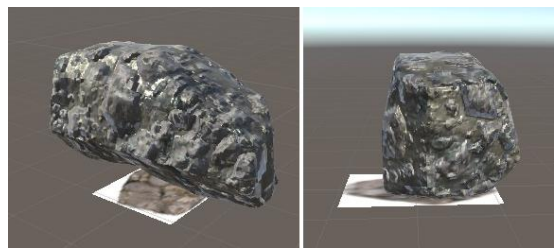

Figure 2

3D Sediment Rock Objects using AR Media

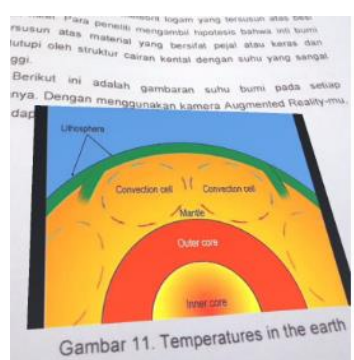

Figure 3

Earth Convection Animation

In addition to the camera menu, there is a quiz menu, containing questions about the structure of the earth and rocks to measure students' critical thinking and thinking abilities. This evaluation sheet is integrated with Google Form. Figure 4 is the front page display and contents of the quiz menu on the Google Form page. 


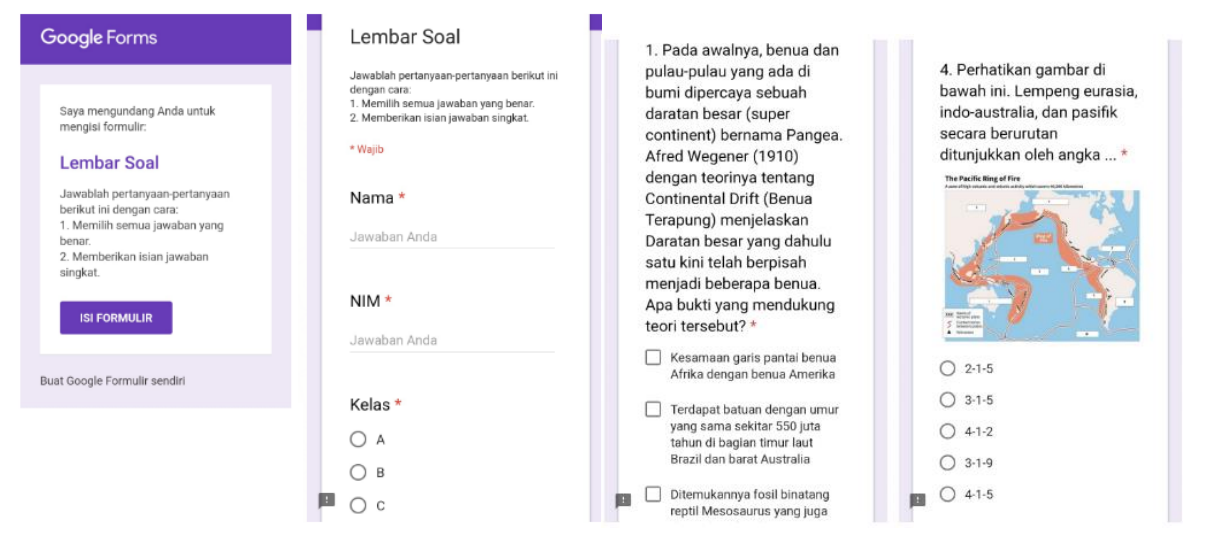

Figure 4

Quiz Menu Page on the Google Form Page

The About menu is a menu containing an explanation or description of the media. This menu contains application titles, developer names. The use of this application is equipped with supporting teaching materials developed as a multimedia companion. This teaching material contains material equipped with markers that can be detected by AR cameras to present 3D objects, animations, and videos.

The results of the media prototype assessment by material experts obtained an average score of 3.41. The assessment by material experts are known that interactive multimedia based on augmented reality relating to earth and rock structure material can help process critical thinking skills, namely, students are actively involved in learning activities in finding information, finding, analyzing, and solving problems. Material relating to rock characteristics needs to be improved because factual accuracy with the original media changes, for example in rock color, rock texture, and rock structure.

Meanwhile, the results of the media prototype assessment by media experts are known that the presentation of material through interactive multimedia based on augmented reality in learning earth and rock structures is considered good, with an average score of 3.02. However, the prototype was revised in several respects, consisting of interactive aspects, concept maps, and administrative aspects of teaching materials. Teaching materials need to provide questions when students scan 3D objects through AR cameras. Thus, learning will be more interactive and stimulate students to skillfully solve problems. In addition, in the aspect of the concept map, teaching materials need to contain a competency map to show how far the material will be reviewed by the user. As for the administrative aspects of writing teaching materials need to be improved, especially the use of numbering is more recommended scientifically, not points in the form of spheres and checklists.

Improvements according to material experts were carried out in the presentation of 3D rock objects that were more able to adjust the colors, textures, and more original rock structures. In addition to $3 \mathrm{D}$ objects, the presentation of animations and videos is 
assessed to provide completeness to the media developed. The results of expert evaluations indicate that the media developed has been used properly after revisions to aspects of the display, programming, and curriculum, and learning. Prototype improvements have been carried out such as addition of questions to the analysis column in Figure 5 and addition of material scope in Figure 6.

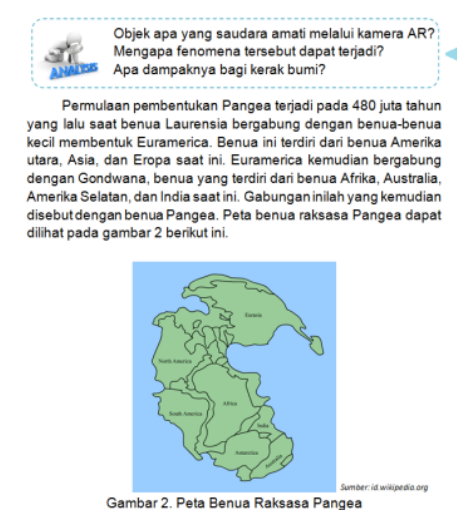

Figure 5

Addition of Questions to the Analysis Column

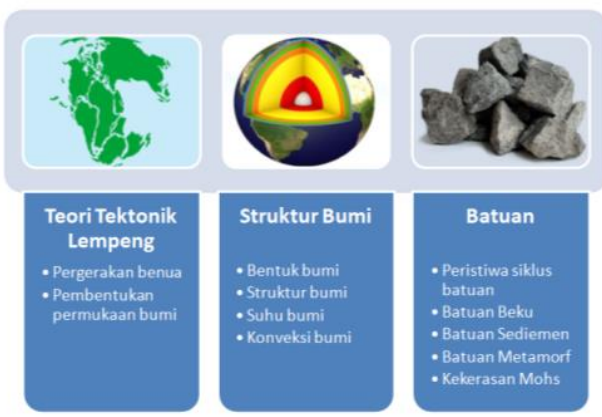

Figure 6

Addition of Material Scope

\section{Preliminary Field Testing}

The interactive multimedia prototype based on augmented reality (AR) which has been revised based on expert input is then tested on a small scale called the preliminary field testing. Preliminary field testing was carried out through activities involving 10 students. The implementation of limited trials was carried out collaboratively along with lecturers in the subject of Basic Science Concepts. The test results of students' critical thinking skills in learning earth and rock structures at the preliminary field-testing stage presented in Figure 7. 


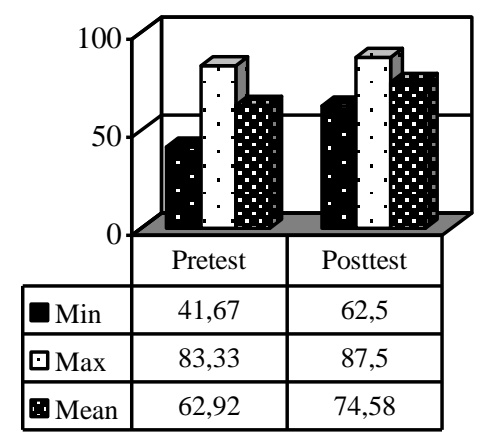

Figure 7

The Preliminary Field-Testing Data

The results in Figure 7 show that students' critical thinking skills after learning using AR-based interactive multimedia were better than before learning using AR-based interactive multimedia. This fact confirms that the media prototypes used in this limited trial can be continued at a wider trial stage. Meanwhile, the results of student responses to the use of interactive multimedia based on augmented reality in learning earth and rock structures in elementary school teacher education programs can be seen in the Table 2.

Table 2

Student Responses to Product Prototypes at Preliminary Field Testing

\begin{tabular}{cccc}
\hline No & Aspect & Score & Category \\
\hline 1 & Learning & 2,97 & Good \\
2 & Programming & 3,33 & Very Good \\
3 & Display & 3,20 & Good \\
\hline
\end{tabular}

Based on Table 2, student responses to AR-based interactive multimedia in general were good. In the programming, aspect gets the highest score in the very good category. Students view that the multimedia prototype developed is interesting and easy to use. The input from students at this limited trial stage is that AR cameras are less responsive in detecting markers on several objects, namely on images of continental Pangea, earth structures, sandstone, limestone, and granite.

\section{Main Field Testing}

The main field-testing stage was done through learning the structure of the earth and rocks by using a revised media prototype based on the results of the preliminary field testing. Main field testing involves 34 students who are collaboratively conducted with lecturers who teach the Basic Concepts of Science. The measurement of students' critical thinking skills in learning the structure of the earth in the main field-testing stage is presented in Figure 8. 


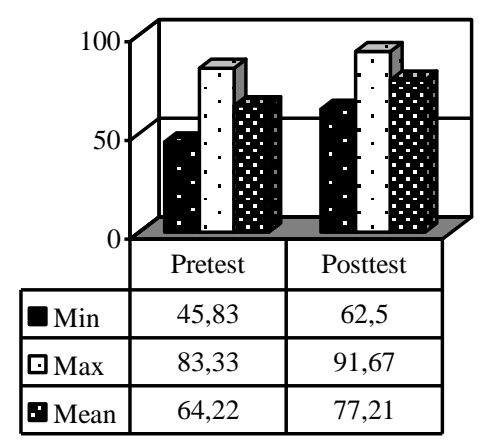

Figure 8

The Main Field-Testing Data

The data in Figure 8 show that students' critical thinking skills after learning using ARbased interactive multimedia were better than before learning using AR-based interactive multimedia. Before testing using the Paired sample t-test, the data of main field testing has been tested for normality using Kolmogorov-Smirnov. The results of normality test at significance level of $5 \%$, obtained $\rho$ value of 0.457 on pretest data and 0.052 in posttest data. The acquisition of $\rho$ value on the normality test show that it was greater than 0.05 , so it can be concluded that the test data is normally distributed. Paired sample t-test was conducted to determine the significance of the difference in mean pretest with posttest average in a sample group. The results of the paired sample t-test presented in Table 3.

Table 3

The Results of Paired Sample t-test

\begin{tabular}{|c|c|c|c|c|c|c|c|c|}
\hline & \multicolumn{5}{|c|}{ Paired Differences } & \multirow{3}{*}{$\mathrm{t}$} & \multirow{3}{*}{ df } & \multirow{3}{*}{$\begin{array}{l}\text { Sig. } \\
(2- \\
\text { tailed })\end{array}$} \\
\hline & \multirow[t]{2}{*}{ Mean } & \multirow[t]{2}{*}{$\begin{array}{l}\text { Std. } \\
\text { Deviation }\end{array}$} & \multirow[t]{2}{*}{$\begin{array}{l}\text { Std. } \\
\text { Error } \\
\text { Mean }\end{array}$} & \multicolumn{2}{|c|}{$\begin{array}{l}\text { 95\% Confidence } \\
\text { Interval of the } \\
\text { Difference }\end{array}$} & & & \\
\hline & & & & Lower & Upper & & & \\
\hline $\begin{array}{l}\text { Pair } \\
\text { Pretest- } \\
\text { Posttest }\end{array}$ & -12.98 & 8.50539 & 1.45866 & -15.96 & -10.02 & 8.905 & 33 & .002 \\
\hline
\end{tabular}

Paired sample t-test obtained $\rho$ value $=0.002<0.05$, it can be decided that $\mathrm{H}_{0}$ is rejected. Thus, it is evident that at the confidence level of 95 percent the average posttest score of critical thinking skills of elementary school teacher education students in learning earth structure and rocks is not the same as the pretest score. These results indicate that students' critical thinking ability after learning using AR-based interactive multimedia is better than before learning using AR-based interactive multimedia. 
In addition to the test results, student responses to the use of AR-based interactive multimedia in learning earth and rock structures in primary school teacher education at the main stage of field testing is presented in Table 4.

Table 4

Student Response to Product Prototypes on the Main Field Testing

\begin{tabular}{llll}
\hline No & Aspect & Score & Category \\
\hline 1 & Learning & 3,46 & Very Good \\
2 & Programming & 3,51 & Very Good \\
3 & Display & 3,62 & Very Good \\
\hline
\end{tabular}

Data in Table 4 show that student responses to AR-based interactive multimedia generally reach a very good category. Students argue that multimedia prototypes developed can help to understand the material more easily. Besides being easier to understand the material structure of the earth and rocks, students see that the presentation of media is interesting and makes learning not boring. This finding is different from the initial conditions which indicate that students have not been interested in learning earth and rock structures. Students assess that learning of earth structures and rocks with the help of AR-based interactive multimedia makes students involved in learning and easy to use. Although good results were obtained, improvements were still made by simplifying questions and clarifying work instructions as an improvement in AR-based interactive multimedia products in learning earth and rock structures in primary school teacher education.

\section{DISCUSSION}

The development phase of AR-based interactive multimedia in learning earth and rock structures begins with the preparation of media products. Analysis of the scope of learning material is carried out to prepare visual objects that can be aired through AR. In general, the preparation of AR-based interactive multimedia in this study refers to good multimedia aspects, consisting of aspects of learning, programming, curriculum, and appearance (Sudatha \& Tegeh, 2015). The development of interactive multimedia uses augmented reality technology as a media base so that its compilation has AR characteristics, such as combining $2 \mathrm{D}$ and $3 \mathrm{D}$ objects, is interactive, and presents various animations and videos (Tekedere \& Göker, 2016; Azuma, 1997).

The media prototype was assessed by experts and at the same time received input as a prototype repair material. The revised prototype was subsequently implemented at the limited trial stage. The results of the implementation of a limited trial showed that the media prototype was in a good category, but improvements were made according to the input of the users in the limited trials. The results of the improvement of media prototypes were then tested on a wider scale. The use of AR-based interactive multimedia facilitates knowledge will be shared between teachers and students, and teachers and students will share authority. Therefore, students control their own learning processes and manipulate unreal objects in the environment to gain understanding and knowledge (Wang, 2012). 
Through trials of AR-based interactive multimedia prototypes at the wider trial stage, the use of AR-based interactive multimedia has a positive impact on the learning process of earth and rock structures in elementary school teacher education programs. The use of AR-based interactive multimedia prototypes provides new experiences to students in learning activities of earth and rock structures. Students are actively involved in learning, such as finding and finding information about learning materials, interpreting data found, analyzing, arguing, and solving problems related to earth and rock structure material independently. Results relevant to Garrett, e al, (2015) concluded that the use of AR technology and the ability to access it can support independent learning.

The role of AR-based interactive multimedia can be seen in aspects of critical thinking. The use of AR-based multimedia can help students find data or information that helps them understand the material in depth about the material structure of the earth and rocks, so AR can support the ability to think critically (Sirakaya \& Sirakaya, 2018; Chang \& Hwang, 2018; Yuliono, et al., 2018; Kurniawan, et al., 2018). The results of this study are relevant to the results of previous research and development that are oriented towards improving critical thinking skills. The development of teaching books with augmented reality technology on the concept of the digestive system can improve the ability of high school students to analyze problems related to the concept of digestion (Amir, 2017). In addition to the concept of digestion, the development of interactive learning media based on augmented reality technology can improve the problem solving skills of high school students in chemical bonding material (Nur, 2015). The use of Augmented Reality media can stimulate the mindset of students in thinking critically about something because they can visualize abstract concepts (Mustaqim, 2017). AR makes it easy for users to understand the spatial relationships of their parts, so that in the Deshpande \& Kim (2018) study the use of AR can improve the ability to solve spatial problems so that it supports technical tasks related to object assembly. In this study, presentation of 3D objects in real time through the AR cameras can help students solve problems. In addition, AR-based interactive multimedia can facilitate interactive learning, meaning there is feedback in the form of ideas, arguments, interpreting data and providing explanations, as well as the results of problem-solving in the matter of earth and rock structures.

\section{CONCLUSION}

The development of AR-based interactive multimedia in learning the material science of earth and rock structures in primary school teacher education program can improve understanding of concepts, their application in connecting concepts, and analyzing data for problem-solving. Product improvements at the development stage produce AR-based interactive multimedia that is feasible to be used by elementary school teacher education students to improve critical thinking skills in science learning. This media is in accordance with the views of experts and users.

\section{REFERENCES}

Afandi, \& Sajidan. (2017). Stimulasi keterampilan berpikir tingkat tinggi. Surakarta: UNS. 
Amir, I. (2017). Pengembangan buku ajar dan augmented reality (AR) pada Konsep sistem pencernaan di sekolah menengah atas (Unpublished master thesis). Makassar: Universitas Negeri Makassar.

Antonioli, M., Blake, C., \& Sparks, K. (2014). Augmented reality applications in education. The Journal of Technology Studies, 40(2), 96-107.

Arista, F. S., \& Kuswanto, H. (2018). Virtual physics laboratory application based on the android smartphone to improve learning independence and conceptual understanding. International Journal of Instruction, 11(1), 1-16.

Azuma, R. T. (1997). A survey of augmented reality. Presence: Teleoperators and Virtual Environments, 6(4), 355-385.

Cai, S., Wang, X., \& Chiang, F. K. (2014). A case study of augmented reality simulation system application in a chemistry course. Computers in Human Behavior, 37, 31-40.

Chang, S. C., \& Hwang, G. J. (2018). Impacts of an augmented reality-based flipped learning guiding approach on students' scientific project performance and perceptions. Computers and Education, 125, 226-239.

Deshpande, A., \& Kim, I. (2018). The Effects of augmented reality on improving spatial problem solving for object assembly. Advanced Engineering Informatics, 38, 760-775.

Estapa, A., \& Nadolny, L. (2015). The effect of an augmented reality enhanced mathematics lesson on student achievement and motivation. Journal of STEM Education: Innovations and Research, 16(3), 40-48.

Garrett, B. M., Jackson, C., \& Wilson, B. (2015). Augmented reality m-learning to enhance nursing skills acquisition in the clinical skills laboratory. Interactive Technology and Smart Education, 12(4), 298-314.

Grubert, J., \& Grasset, R. (2013). Augmented reality for android application development. Birmingham: Packt Publishing.

Haag, J. (2013). Using Augmented reality for contextual mobile learning. Retrieved from https://www.learningsolutionsmag.com/articles/1310/using-augmented-reality-forcontextual-mobile-learning.

Irawan, T. A., Rahardjo, S. B., \& Sarwanto. (2017). Analisis kemampuan berpikir kritis siswa kelas VII-A SMP negeri 1 jaten. Prosiding Seminar Nasional Pendidikan Sains (pp. 232-236). Surakarta: Universitas Sebelas Maret.

Joan, R. (2015). Enhancing education through mobile augmented reality. I-Manager's Journal of Educational Technology, 11(4), 8-14.

Kesim, M., \& Ozarslan, Y. (2012). Augmented reality in education: Current technologies and the potential for education. Social and Behavioral Sci., 47, 297-302.

Kurniawan, M. H., Suharjito, Diana, \& Witjaksono, G. (2018). Human anatomy learning systems using augmented reality on mobile application. Procedia Computer Science, 135, 80-88.

Liang, S., \& Roast, C. (2014). Five features for modeling augmented reality. In HCI 
International 2014 - Posters' Extended Abstracts. Constantine: Springer.

Martín-Gutiérrez, J., Luís Saorín, J., Contero, M., Alcañiz, M., Pérez-López, D. C., \& Ortega, M. (2010). Design and validation of an augmented book for spatial abilities development in engineering students. Computers \& Graphics, 34(1), 77-91.

Miles, M. B., \& Huberman, A. M. (1994). Qualitative data analysis. London: Sage.

Morris, N. P., \& Lambe, J. (2017). Multimedia interactive ebooks in laboratory bioscience education. Higher Education Pedagogies, 2(1), 28-42.

Mustaqim, I. (2017). Pemanfaatan augmented reality sebagai media pembelajaran. Jurnal Pendidikan Teknologi dan Kejuruan, 13(2), 174-183.

Nur, A. I. (2015). Pengembangan media pembelajaran interaktif berbasis teknologi augmented reality pada materi ikatan kimia. (Unpublished master thesis). Jakarta: Universitas Islam Negeri Syarif Hidayatullah.

Ozdemir, M., Sahin, C., Arxagok, S., \& Demir, M. K. (2018). The effect of augmented reality applications in the learning process: A meta analysis study. Eurasian Journal of Educational Research, 74, 165-186.

Puspitarini, Y. D., Akhyar, M., \& Djono, D. (2018). Developing powtoon-based video learning media for five grade students of elementary school. Proceedings of the Int. Conference of Communication Science Research 2018 (pp.173-177). Paris: Atlantis.

Rajendra, M. I., \& Sudana, M. I. (2018). The Influence of interactive multimedia technology to enhance achievement students on practice skills in mechanical technology. Journal of Physics: Conference Series, 953, 1-5.

Sirakaya, M., \& Sirakaya, D. A. (2018). Trends in educational augmented reality studies: A systematic review. Malaysian Online of Educ. Technology, 6(2), 60-74.

Sudatha, I. G. W., \& Tegeh, I. M. (2015). Desain multimedia pembelajaran. Yogyakarta: Media Akademi.

Sukmadinata, N. (2013). Metode penelitian pendidikan. Bandung: Remaja Rosdakarya.

Susetyarini, E., A, K., Fitriasari, R. R., \& Fauzi, A. (2018). Developing 3D instructional media takbulta for the sub-theme of potential sources of energy in Indonesia. International Journal of Advanced Research, 6(12), 916-924.

Tekedere, H., \& Göker, H. (2016). Examining the effectiveness of augmented reality applications in education: A meta-analysis. International Journal of Environmental and Science Education, 11(16), 9469-9481.

Wang, X. Y. (2012). Augmented reality: A new way of augmented learning. Retrieved from https://elearnmag.acm.org/archive.cfm?aid=2380717.

Widiansyah, A. T., Indriwati, S. E., Munzil, \& Fauzi, A. (2018). I-invertebrata as an android-based learning media for molluscs, arthropods, and echinoderms identification and its influence on students' motivation. J. Pendidikan Biologi Indonesia, 4(1), 43-52.

Yuliono, T., Sarwanto, \& Rintayati, P. (2018). The promising roles of augmented reality in educational setting: A review of the literature. Int. J. of Educ. Meth., 4(3), 125-132. 